\title{
ANALISA HUKUM PERALIHAN HAK TANAH ULAYAT KAUM YANG BELUM DIDAFTARKAN DI KABUPATEN DHARMASRAYA*
}

\author{
"Ratih Agustin Wulandari ${ }^{1}$, Muhammad Sukron' ${ }^{2}$, Raimon Efendi ${ }^{3}$ \\ Fakultas Hukum dan Ekonomis Bisnis, Universita Dharmas Indonesia, Dharmasraya \\ *e-mail: ratihagustinwulandari@undhari.ac.id ${ }^{1}$ \\ e-mail: muhammadsukron20@gmail.com² \\ e-mail: raimon.efendi@gmail.com ${ }^{3}$
}

\begin{abstract}
Ulayat land has a social function passed down from ancestors. Tanah Ulayat is a customary community right that cannot be transferred to outsiders, in the Minangkabau kinship system, it is only used for 4 things: gadang girly house, dead body lying in the middle of the house, unmarried girls, upholding the heirloom title. However, at the moment there are a lot of transfers of customary land rights, both sale and purchase. The research uses an empirical juridical approach. The data used are primary data obtained by interview and secondary data obtained through literature study. The results of research into the existence of the transfer of rights to customary land that have not been registered are increasingly high, namely in the form of buying and selling, which has an impact on the social function of customary land has been lost. The practice of buying and selling communal land for people in Koto Baru in the Dharmasraya Regency consists of buying and selling a plot of land and buying and selling a plot of land followed by a customary land grant. Collective Rights on customary land will change to individual rights if there is a transfer of rights to the communal land. This will result in ulayat land which will become private / individual land that will automatically cause harm to the people themselves. Customary philosophical values will fade both high pusako property and low pusako property. And no longer subject to the provisions of customary law.
\end{abstract}

Keywords : The Transfer Of Rights; Ulayat Land; Races Has Not Been Registered.

\begin{abstract}
Abstrak
Tanah ulayat mempunyai fungsi sosial yang diturunkan nenek moyang. Tanah Ulayat adalah hak masyarakat adat yang tidak dapat dialihkan pada pihak luar, dalam system kekerabatan Minangkabau hanya digunakan untuk 4 hal : rumah gadang ketirisan, mayat terbujur di tengah rumah, anak gadis belum kawin, menegakkan gelar pusaka. Namun saat ini banyak sekali terjadi peralihan hak atas tanah ulayat baik jual beli maupun hibah. Penelitian menggunakan pendekatan yuridis empiris. Data yang digunakan adalah data primer yang diperoleh dengan wawancara serta data sekunder yang diperoleh melalui studi kepustakaan. Hasil penelitian eksistensi peralihan hak atas tanah ulayat yang belum didaftarkan semakin tinggi yaitu dalam bentuk jual beli, yang berdampak pada fungsi sosial tanah ulayat telah hilang. Praktek jual beli tanah ulayat kaum di Koto Baru Kabupaten Dharmasraya terdiri dari jual beli sebidang kebun dan jual beli sebidang kebun diikuti hibah tanah ulayat. Hak Kolektif pada tanah ulayat akan berubah menjadi hak individual jika terjadi peralihan hak pada Tanah ulayat kaum. Ini semua akan berakibat dimana tanah ulayat akan menjadi tanah milik individu / pribadi yang otomatis menimbulkan kerugian bagi kaum itu sendiri. Nilai-nilai falsafah adat akan luntur baik harta pusako tinggi, maupun harta pusako rendah. Dan tidak lagi tunduk pada ketentuan hukum adat.
\end{abstract}

Kata Kunci: Peralihan Hak; Tanah Ulayat; Kaum; Belum Didaftarkan.

\footnotetext{
* Naskah diterima: 10 Juli 2020, direvisi: 14 September 2020, disetujui untuk terbit: 28 September 2020

Doi: $10.3376 /$ jch.v6i1.274
} 


\section{PENDAHULUAN}

Tanah mempunyai kedudukan yang penting bagi bangsa Indonesia. Tanah dan masyarakat saling berhubungan dan tidak dapat dipisahkan. Pentingnya tanah dalam kehidupan manusia dapat dilihat dimana tidak hanya dalam hidupnya saat matipun manusia masih membutuhkan tanah.

Asset Negara Indonesia yang penting dan mendasar adalah Tanah, dan tak dapat dipungkiri diatas tanahlah berkembangnya Negara dan bangsa. Masyarakat Indonesia memposisikan tanah pada kedudukan yang sangat penting dan dalam produktivitas agrarian tanah adalah faktor pendukung utama. Benda tidak bergerak yang mutlak sangat diperlukan dalam kehidupan manusia adalah tanah, berakibat tanah menjadi objek jual beli yang sangat diminati.

Kelebihan dari tanah dilihat dari harga tanah yang terus meningkat dan mudah dijual dan dapat dijadikan objek jaminan bagi perjanjian kredit. Saat ini banyak sekali terdapat tanah ulayat yang diperjual belikan dengan berbagai alasan, dan sudah tidak mengacu lagi kepada ketentuan adat.

Hukum agraria yang berlaku atas bumi, air dan ruang angkasa ialah hukum adat, sepanjang tidak bertentangan dengan kepentingan nasional dan negara, yang berdasarkan atas persatuan bangsa dengan sosialisme Indonesia serta dengan peraturan perundang-undangan yang tercantum dalam undang-undang ini dengan peraturan perundang-undangan lainnya. Segala sesuatu dengan mengindahkan unsur-unsur yang bersandar pada hukum agama.(UndangUndang Nomor 50 Tahun 1960)

Hak ulayat adalah hak tertinggi dalam hukum adat dan tak jarang selalu dikaitkan dengan tanah yang biasa dikenal dengan hak tanah ulayat. Dalam Undangundang Pokok Agraria (UUPA) tidak dijelaskan secara implisit tentang tanah ulayat, namun sejak adanya Undangundang No 5 Tahun 1960 Tentang Peraturan dan Dasar Pokok Agraria (UUPA). Hak Ulayat diakui sebagai suatu hak atas tanah apabila memenuhi suatu persyaratan yang telah ditentukan. (Ilyas Ismail, 2010)

Persekutuan hukum seperti nagari, desa maupun suku mempunyai hak untuk menguasai tanahnya yang juga disebut dengan Hak ulayat seperti yang dijelaskan dalam Pasal 1 ayat (1) Peraturan Menteri Negara Agraria/Kepala Badan Pertanahan Nasional Nomor 5 Tahun 1999 Tentang Pedoman Penyelesaian Masalah Hak Ulayat Masyarakat Hukum Adat. Namun semua pelaksanaannya diatur oleh ketua persekutuan atau kepala kaum.

Tanah dan perairan merupakan objek dari hak ulayat. Tanah yang dimiliki secara bersama adalah Tanah ulayat, hak ulayat sebagai istilah teknis hukum adalah hak yang melekat sebagai kompetensi hak pada masyarakat hukum adat berupa wewenang/kekuasaan mengurus dan mengatur tanah seisinya dengan daya laku ke dalam maupun keluar.(L. H. Sigiro, 2016) 
Ratih Agustin Wulandari, Muhammad Sukron, Raimon Efendi: Analisa Hukum...

UUPA bersumber dari hukum adat dimana dalam Pasal 3 UUPA bahwa hak ulayat diakui sebagai suatu hak atas tanah apabila dalam kenyataannya memang masih ada dan pelaksanaan hak tersebut harus sesuai dengan kepentingan nasional serta tidak boleh bertentangan dengan ketentuan perundang-undangan. (Ilyas Ismail, 2010)

Persyaratan dalam Pasal 3 UUPA tersebut dalam kenyataannya mengandung multi tafsir, karena adanya kesamaan pemahaman dan penafsiran, dan masih ditemui berbagai ketentuan perundang-undangan masih menempatkan hak ulayat pada posisi yang berbeda dan bertentangan. Hal ini yang dapat memicu terjadinya konflik dalam penguasaan tanah ulayat. (D. K. Kobu, 2017)

Warga negara Indonesia mempunyai kebebasan untuk memiliki penguasaan hak-hak atas tanah seperti hak milik bahkan atas tanah yang dikuasai negara berdasarkan UUPA. Permohonan hak milik tersebut dapat dilakukan atas dasar Pasal 8 sampai dengan Pasal 16 Peraturan Menteri Agraria/Kepala BPN Nomor 9 Tahun 1999 tentang Tata Cara Pemberian Dan Pembatalan Hak Atas Tanah Negara dan Hak Pengelolaan (untuk selanjutnya disebut Permen Agraria No. 9 Tahun 1999).[( S. R. Fatmi and U. Jember, 2018)

Namun saat ini ada perkembangan pengaturan tentang tanah ulayat yang terdapat dalam Pasal 8 Peraturan Daerah Sumatera Barat Nomor 16 Tahun 2008 Tentang Tanah Ulayat dan Pemanfaatannya dimana untuk menjamin kepastian hukum dan keperluan penyediaan data/informasi pertanahan, tanah ulayat sebagaimana yang dimaksud dalam Pasal 5 dapat didaftarkan pada kabupaten /kota.

Hal ini tentu membuka peluang bagi masyarakat di Sumatera Barat yang mana tidak dapat dipungkiri sebagian besar tanahnya merupakan tanah ulayat. Transaksi jual beli tanah ulayat di Sumatera Barat khususnya Kabupaten Dharmasraya semakin marak dan berkembang baik tanah ulayat yang telah didaftarkan maupun yang belum didaftarkan. Kondisi ini bertentangan dengan sifat tanah ulayat yang tidak boleh diperjualbelikan atau dipindahtangankan.

Sumatera Barat yang disebut dengan Minangkabau dimana mamak kepala waris adalah pucuk penentu, dimana segala sesuatu menyangkut tanah ulayat perlu mendapat persetujuan mamak kepala waris dan anggota kaum sebagai pemilik dari tanah ulayat tersebut. Untuk melakukan perbuatan dan hubungan hukum terhadap tanah ulayat diwakilkan kepada mamak kepala waris atas nama kaumnya.

Di minangkabau tanah pusaka tinggi dapat digadaikan atas 4 alasan berikut: (1) Rumah gadang katirisan (rumah gadang ketirisan), (2) Mayik tabujua ditangah rumah (mayat terbujur di tengah rumah), (3) Gadih gadang tak balaki ( anak gadis belum kawin), (4) Mambangkik batang tarandam (menegakkan gelar pusaka).

Sertifikat adalah tanda bukti hak yang kuat atas tanah. Sertifikat didaftarkan pada Badan Pertanahan Nasional (BPN) 
atau telah bersertifikat. Namun, masih banyak masyarakat yang tidak mendaftarkan tanah mereka terutama Tanah Ulayat. Tanah Ulayat atau dikenal dengan 'communal bezitrecht" adalah tanah milik bersama dimana yang berhak atas tanah tersebut adalah anggota kaumnya.

Resiko hukum peralihan hak atas tanah yang belum terdaftar (bersertifikat) tergolong rendah. Namun, saat ini banyak sekali terjadi peralihan hak tanah ulayat yang belum didaftarkan termasuk di Kabupaten Dharmasraya.

Tanah ulayat di Minangkabau terdiri dari: (Sjahmunir, 2000) (1).Tanah Ulayat kaum ialah tanah ulayat yang dimiliki oleh suatu kaum dengan ke penguasaannya oleh Kapala Kaum atau Mamak Kepala Waris, (2) Tanah Ulayat Suku ialah tanah ulayat yang dimiliki oleh sesuatu suku dengan penguasaannya oleh kepala suku atau Penghulu suku, (3) Tanah Ulayat Nagari ialah tanah ulayat yang dimiliki oleh seluruh anak nagari atau anak kemenakan dengan penguasaannya penghulu-penghulu suku yang ada di nagari bersangkutan.

Tanah ulayat merupakan tanah merupakan harta pusaka tinggi kaum, yang bersifat hak public, ditujukan untuk kaum demi kepentingan kaum, yang tak dapat dikuasai oleh orang di luar kaum. Namun saat ini telah mengalami perkembangan, dimana tanah harta pusaka tinggi banyak yang telah dialihkan atau dijual sehingga menjadi bersifat keperdataan. Ini sangat bertentangan dengan ketentuan hukum adat
Minangkabau yang menganut garis keturunan matrilineal.

Minangkabau mempunyai sistem kekerabatan matrilineal yang berbeda dengan daerah lain yang banyak menganut patrilineal, dimana garis keturunan berdasarkan garis keturunan ibu. Ini adalah ciri khas kebudayaan Minangkabau dengan sistem kekerabatan matrilineal yang tumbuh dan berkembang dalam masyarakat Sumatera Barat. ( M. Munir, 2015)

Pembagian tanah ulayat secara utuh, tidak terbagi dan tidak boleh dibagi dengan cara turun temurun, dari generasi ke generasi. Terlihat dalam fatwa adat yang menyatakan Babrik-birik tabang ka sawah (Birik-birik terbang ke sawah) Dari sawah tabang ka halaman (Dari sawah terbang ke halaman) Basuo di tanah bato (Bertemu di tanah bata) Dari niniak turun ka mamak (Dari ninik turun ke mamak) Dari mamak turun ke kamanakan (Dari mamak turun ke kemanakan) Patah tumbuah hilang berganti (Patah tumbuh hilang berganti) Pusako baitu juo Pusaka begitu juga ). ( Nasroen. M, 1971)

\section{METODE PENELITIAN}

Penelitian ini menggunakan pendekatan Yuridis Empiris, pendekatan Yuridis (Hukum dilihat sebagai Norma atau das solen) karena dalam membahas permasalahan penelitian ini menggunakan bahan-bahan hukum tertulis, kemudian bahan hukum primer dan bahan hukum sekunder pendekatan empiris (Hukum sebagai kenyataan social, cultural atau das sein), karena dalam penelitian ini 
Ratih Agustin Wulandari, Muhammad Sukron, Raimon Efendi: Analisa Hukum...

menggunakan data premier yang diperoleh dari lapangan. (R. Syarfina, 2019) Pelitian ini bersifat Deskriptif, yaitu penelitian yang memberikan data tentang sesuatu atau gejala-gejala sosial yang berkembang di tengah-tengah masyarakat sehingga dengan adanya penelitian ini diharapkan dapat memperoleh gambaran yang menyeluruh, lengkap dan sistematis tentang objek yang akan di teliti. Jenis data yang digunakan untuk mengumpulkan informasi terdiri dari data primer dan data sekunder. ( HS Salim, 2016) Data Primer didapat dari masyarakat, pemegang ulayat di Kabupaten Dharmasraya sedangkan data sekunder dari berbagai literatur atau peratutran perundang-undangan yang terkait.

\section{HASIL DAN PEMBAHASAN}

\section{Eksistensi Peralihan Hak Atas Tanah Ulayat Yang Belum Didaftarkan di Kabupaten Dharmasraya.}

Peralihan hak tanah ulayat yang sering terjadi adalah jual beli, gadai dan hibah. Di Kabupaten Dharmasraya peralihan hak yang sering dilakukan masyarakat adatnya adalah jual beli dan gadai. Beberapa alasan diizinkannya menggadai tanah ulayat di Kabupaten Dharmasraya yaitu (1) Jika ada yang meninggal tetapi si mayat tidak mempunyai harta yang ditinggalkan, maka kaum dapat menjual tanah harta pusako tinggi untuk menutup biaya penyelenggaraan jenazah sampai terkuburkan, (2) Jika ada rumah adat milik kaum yang rusak maka tanah harta pusako tinggi di jual untuk memperbaikinya, (3) Jika ada utang kaum yang membuat malu kaum maka tanah harta pusako tinggi dijual untuk menutupinya, (4) Biaya batagak panghulu, (5) Jika ada kemenakan perempuan, cucu perempuan kaum yang telah berumur tapi belum berumah tangga, maka tanah harta pusako tinggi digunakan untuk memberikan imbalan kepada seseorang laki-laki yang mau menikahinya.

Namun saat ini alasan untuk menggadaikan tanah ulayat kaum sudah beragam, tanah ulayat kaum bisa digadaikan dengan alasan apapun juga, tidak hanya menyangkut 5 (lima) tersebut. Seperti biaya memperbaiki irigasi, biaya naik haji, biaya sekolah anak, membayar hutang darah ataupun hutang bersama dan lain-lain.

Ketentuan adat Minangkabau menjelaskan jika kaum hampir punah maka tanah ulayatnya dapat dialihkan kepada pihak luar. Punah dalam hukum adat di minangkabau artinya tak ada lagi ahli waris sesuai garis keturunan ibu.

Sebagian besar tanah ulayat di Kabupaten Dharmasraya belum didaftarkan (bersertifikat). Tanah yang letaknya jauh dari pemukiman atau rimba adalah milik kaum, dimana kemanakan maupun cucu-cucu dari pemegang ulayat dapat mengolah tanah ini baik berkebun maupun bertani inilah yang disebut tanah ulayat kaum sebagai harta pusaka tinggi sedangkan ranah, sawah dan ladang yang berada di sekitar kampung yang penguasaannya secara turun temurun oleh 
kelompok dalam satu kaum disebut tanah ulayat sebagai harta pusaka rendah.

Bentuk Peralihan hak tanah ulayat di Kabupaten Dharmasraya berupa jual beli kebun dan jual beli yang diikuti hibah. Dahulu semua bentuk peralihan hak atas tanah ulayat di Kabupaten Dharmasraya berawal secara lisan. Sesuai perkembangan dan kebutuhan dan dituntut peraturan, maka peralihan hak atas tanah secara tertulis dan dibawah tangan. Di Kabupaten Dharmasraya peralihan hak tanah ulayat banyak berdasarkan alas hak yang ditanda tangani oleh penguasa kaum. Berdasarkan Peraturan Pemerintah Nomor 24 Tahun 1997 tentang Pendaftaran Tanah, dasar penerbitan sertifikat dapat berupa alas hak di bawah tangan yang dapat dibuktikan. Jika data yang ada di dalam alas hak benar maka dapat digunakan sebagai dasar penerbitan Sertifikat Hak Milik, walaupun alas hak tidak mempunyai kekuatan hukum.

Tidak dapat dipungkiri peralihan hak tanah ulayat yang berupa jual beli akan berujung pada pendaftaran tanah tersebut, dimana secara alamiah kepemilikan bersama semakin menyempit akibat individualisasi tanah (HS Salim , 2016). Tanah-tanah ulayat kaum (harta pusaka tinggi maupun harta pusaka rendah) di Kabupaten Dharmasraya banyak yang sudah beralih kekuasaan pada pihak pendatang maupun pihak asing dan perusahaan perusahaan besar yang mengelola tanah tersebut menjadi lahan perkebunan perusahaan (seperti PT. SMP,
AWB dan Incasi Raya), pabrik dan lainlain.

Tanah yang belum didaftarkan hak kepemilikannya atau tidak ada sertifikatnya, memiliki resiko hukum dan kerawanan yang lebih tinggi (A. Hartanto, 2012). Peralihan hak tanah ulayat di Kabupaten Dharmasraya banyak dilakukan melalui alas hak yang dikeluarkan oleh kepala suku atau kaum yang biasa disebut datuk penghulu atau mamak kepala waris.

Alas hak atas tanah adalah dasar untuk dapat memiliki hak atas tanah, ini merupakan persoalan yang sangat penting bagi masyarakat. Alas hak merupakan surat di bawah tangan dimana keberadaannya, sebagai salah satu pembuktian hak dalam penerbitan sertifikat pada kantor pertanahan, dapat menimbulkan ketidakpastian bagi pemegang hak. Akibatnya, meskipun sertifikat merupakan alat bukti yang kuat bagi pemegangnya, namun hal tersebut belum bisa memberikan jaminan adanya kepastian hukum bagi mereka. (K. Mohammad Jeffry Maulidi, 2017)

\section{Hak Kaum Sebagai Pemilik Tanah Ulayat yang Belum Didaftarkan Terhadap Harta Pusaka Tinggi Kaum yang Telah Mengalami Peralihan Hak.}

Dalam falsafah adat Minangkabau ulayat merupakan kekuasan turun temurun atas tanah dan segala sesuatu yang ada diatas tanah tersebut, dan menikmati segala sesuatu yang ada dilingkungan hidupnya dan 
memanfaatkan sumber daya yang ada untuk bertahan hidup dan berkembang. Hubungan yang terjalin antara kaum dan tanah menimbulkan Istilah beschikkings ( hak ulayat ) yang dapat diterima masyarakat. Menurut Van Vollenhoven hak ulayat adalah merupakan tiang kedua dari tiang-tiang hukum'. Sebagai tiang pertamanya adalah persekutuan hukum, hal ini dapat dipahami bahwa memang untuk adanya suatu hak ulayat harus ada persekutuan hukum yang mengklaim suatu wilayah tertentu atau areal tanah tertentu sebagai daerah yang dimiliki bersama. (B. Muhammad, 1991)

Berdasarkan hukum adat yang berlaku di Minangkabau, ruang lingkup hak ulayat itu tak dapat dipisahkan baik antara tanah, air, dan sumber daya alam yang terkandung di dalamnya. Ibarat pepatah adat sekalian nego hutan tanah, mulai dari batu/pasie nan saincek, rumpuik nan sahalai, jirek nan sabatang, ka atehnyo taambun jantan, ka bawah sampai takasiak bula, pangkek penghulu punyo ulayat (sekalian yang ada di tanah hutan, mulai dari batu/pasir sebutir, rumpuik sehelai, pohon jarak yang sebatang, ke atasnya sampai ke angkasa, ke bawahnya sampai ke dalam bumi adalah ulayat). (Titin Fatimah dan Hengki Andora, th)

Kebutuhan kaum dapat dipenuhi dengan tanah ulayat kaum, yang merupakan hak kolektif (bersama) anggota kaum yang bersangkutan bukan hak individu, yang tidak dapat dipindah tangankan secara permanen, kecuali dalam keadaan terdesak. Keberadaan hak ulayat dapat dilihat dari 3 ( tiga ) unsur yaitu: unsur masyarakat adat, unsur wilayah dan unsur masyarakatnya dengan wilayah. (Nasroen. M, 1971)

Pasal 26 ayat (1) UUPA memberikan perlindungan terhadap warga negaranya yang benar-benar mempunyai hak atas tanah, dimana "jual beli, penukaran, penghibahan, pemberian wasiat, pemberian menurut adat dan perbuatanperbuatan lain yang dimaksudkan untuk memindahkan hak milik serta pengawasannya diatur dengan peraturan pemerintahan'.

Pihak lain selain dari anggota kaum dapat memanfaatkan tanah ulayat, tapi harus mendapatkan persetujuan dari pimpinan dan anggota kaum, dan membayar recognitie kepada pemilik tanah ulayat. Namun saat ini banyak sekali terjadi jual beli tanah ulayat karena kebutuhan lahan untuk pertanian, perkebunan, kawasan industri dan lainlain. Dan tidak dapat dipungkiri tanah ulayat saat ini dapat beralih pada pihak lain di luar kaumnya.

Dalam prakteknya di Kabupaten Dharmasraya, berdasarkan surat pelepasan hak tanah ulayat kaum dapat dikuasai dan dimiliki, seperti melalui hibah, pemberian adat atau wasiat (sebagaimana tertera dalam UUPA) dengan prosedur pertama tanda tangan kepala kaum (ampek jinih), kedua Ketua Kerapatan Adat Nagari (KAN) beserta Wali Nagari mengetahui. Jika prosedur diatas dilakukan maka hilanglah hak cucu kemenakan dan tidak dapat menuntut. Tapi anggota kaum dapat menuntut dan 
membatalkan jual beli jika prosedur diatas tidak dilakukan.

Karena pada dasarnya tanah ulayat sebagai harta pusaka tinggi adalah hak bersama. Jika tanah ulayat yang telah dilakukan peralihan hak, berdasarkan surat jual beli saja, dapat dituntut karena dianggap belum memiliki hak penguasaan penuh, karena kebanyakan dalam surat jual beli dibawah tangan klausanya tidak dibuat secara jelas hanya tertera jual beli sebidang kebun yang dapat diartikan tidak beserta tanahnya. Lain halnya dengan orang yang menerima hibah dari pemegang hak ulayat.

Surat hibah atas tanah ulayat yang diberikan oleh penguasa ulayat tidak dapat diganggu gugat. Tanah ulayat yang telah dihibahkan tidak dapat dituntut jika penerima hibah memegang surat hibah.

Etika adat minangkabau barang siapa yang telah mendapat hibah atau tanah yang diperuntukkan secara khusus tersebut diharapkan tidak melakukan jual beli, agar tanah ulayat yang bersifat komunal selalu terjaga kelestariannya. Hibah dari kepala kaum sebagai penguasa ulayat diperuntukkan bagi cucu kemenakannya, untuk kesejahteraan cucu kemenakannya dalam menopang perekonomian dan tanah yang diberikan tersebut tidak diganggu gugat oleh pihak lain.

Pendaftaran tanah ulayat oleh pembeli dimana Tanah ulayat yang telah dilakukan peralihan hak yang sebagian besar dalam bentuk jual beli berakibat hilangnya hak kolektif (bersama) yang melekat pada tanah ulayat menjadi hak individual. Otomatis berdampak kerugian pada kaumnya dan tidak dapat lagi menguasai dan tidak lagi berfungsi untuk kepentingan bersama.

Peralihan hak tanah ulayat mengakibatkan lunturnya nilai-nilai falsafah adat dalam hal tanah ulayat, baik harta pusako tinggi, maupun harta pusako rendah. Tanah ulayat yang merupakan kebanggaan kaum, akan dengan mudahnya dialihkan kepada pihak lain. Seiring perkembangan zaman dapat dilihat sekarang di Kabupaten Dharmasraya tanah ulayat sudah jarang ditemukan karena banyak yang sudah mengalami peralihan hak walau belum didaftarkan.

Peralihan hak tanah ulayat marak terjadi di Kabupaten Dharmasraya terutama Nagari Bonjol. Suku melayu mempunyai tanah ulayat paling luas di Nagari Bonjol, dimana yang berhak memanfaatkan tanah ulayat mereka adalah kaum suku melayu tersebut. Suku melayu bonjol tetap berpegang teguh pada sistem adat dimana tanah ulayat diperbolehkan dijual dengan syarat tertentu sesuai dengan aturan adat dan persetujuan ninik mamak.

Sengketa pernah terjadi di Bonjol dimana masyarakat melakukan perlawanan dengan merebut kembali tanah ulayat mereka yang telah dikuasai oleh perusahaan HTI (DS dan Inhutani) sebagai pemegang izin dari pemerintah (KPHP Dharmasraya) dengan menebang semua pohon milik perusahaan HTI, diawali dengan penebangan pohon jabon 
Ratih Agustin Wulandari, Muhammad Sukron, Raimon Efendi: Analisa Hukum...

(Anthocephalus cadamba) milik DS dan meranti (Shorea leprosula) milik Inhutani. Tanah tersebut kemudian ditanami masyarakat dengan sawit dan karet.

Hal ini terjadi akibat tidak semua masyarakat adat atau kaum dari suku melayu merasakan manfaat atau keuntungan dari Pihak DS dan Inhutani, hanya penguasa adat dan orang-orang terdekatlah yang dapat merasakan keuntungannya. Walaupun sebelum menanam tanah tersebut pihak DS dan Inhutani sudah mendapat izin dari pihak adat melalui perjanjian antara perusahaan dengan pihak adat dengan pemberian sejumlah uang dari pihak perusahaan kepada pihak adat.

Setelah masyarakat menanami lahan dengan karet dan kelapa sawit, berarti lahan tersebut telah menjadi milik masyarakat dan apabila perusahaan ingin mengambil lahan yang telah ditanami masyarakat, pihak perusahaan harus membayar sejumlah uang kepada masyarakat sebagai syarat mengambil lahan. Apabila perusahaan tidak bersedia membayar berarti perusahaan harus merelakan tanah tersebut menjadi hak milik masyarakat.( Nasroen. M, 1971)

\section{SIMPULAN}

Tidak dapat dipungkiri di Kabupaten Dharmasraya eksistensi peralihan hak atas tanah ulayat yang belum didaftarkan semakin tinggi yaitu dalam bentuk jual beli kebun dan hibah lahan perkebunan.

Peralihan hak tanah ulayat dilakukan hanya dengan menggunakan alas hak yang dikeluarkan oleh datuk penguasa ulayat atau kepala kaum. Tidak semua masyarakat kaum merasakan keuntungan dari peralihan tersebut. Inilah yang mengakibatkan terjadinya sengketa dalam masyarakat, hanya penguasa adat dan orang terdekatnyalah yang dapat menikmati keuntungan, yang akhirnya masyarakat kaum yang lain menjadi memberontak sehingga menimbulkan sengketa.

Hal ini berdampak pada fungsi sosial tanah ulayat telah hilang. Sejatinya tanah ulayat digunakan untuk kepentingan kaumnya, Tanah ulayat merupakan warisan dari nenek moyang pasukuan dan mempunyai makna sakral dalam kaum.

Peralihan hak atas tanah ulayat menimbulkan kerugian bagi kaum pemegang ulayat itu sendiri, nilai-nilai falsafah adat akan luntur baik bagi harta pusaka tinggi maupun harta pusaka rendah. Hak Kolektif pada tanah ulayat akan berubah menjadi hak individual jika terjadi peralihan hak pada Tanah ulayat kaum. Ini semua akan berakibat dimana tanah ulayat akan menjadi tanah milik individu / pribadi.

Di Minangkabau kebanggaan sebuah kaum adalah tanah ulayat, yang mana saat ini telah dengan mudahnya berpindah kepada pihak lain. Dimana hampir semua peralihan hak atas tanah ulayat dilakukan secara bawah tangan. Peralihan hak banyak dilakukan atas tanah ulayat yang belum didaftarkan dan hanya demi kepentingan sebagian dari anggota kaum yang otomatis hanya menguntungkan yang berkepentingan saja. Jika Jual beli 
dilakukan secara bawah tangan dan klausa dalam surat jual beli tidak dibuat dengan jelas maka kaum dapat menuntut kembali hak mereka.

\section{UCAPAN TERIMAKASIH}

Peneliti mengucapkan terima kasih kepada Kementrian Riset dan Teknologi / Badan Riset Dan Inovasi Nasional Deputi Bidang Penguatan Riset dan Pengembangan atas dukungan berupa dana penelitian yang membantu berlangsungnya penelitian ini.

\section{DAFTAR PUSTAKA}

Undang-Undang No 5 Tahun 1960 Tentang Peraturan Dasar PokokPokok Agararia.

Ilyas Ismail, "Kedudukan Dan Pengakuan Hak Ulayat Dalam Sistem Hukum Agraria Nasional," KANUN, vol. No. 50 Edi, 2010.

F. Andiki, A. P. Prabandari, P. Studi, M. Kenotariatan, F. Hukum, and U. Diponegoro, "Peralihan hak tanah ulayat di kabupaten dharmasraya," Notarius, vol. 12, pp. 856-865, 2019.

L. H. SIGIRO, "Analisis Hukum Tentang Pendaftaran Tanah Ulayat yang Menjadi Hak Perorangan Pada Tanah Ulayat di Kabupaten Dairi," Premise Law J., vol. 17, 2016.

D. K. Kobu, "Pelaksanaan Peralihan Hak Atas Tanah Berdasarkan Hukum Adat Suku Tobelo di Kabupaten Halmahera Selatan," vol. VI, no. 2, pp. 36-43, 2017.

S. R. Fatmi and U. Jember, "Permohonan Tanah Ulayat di Minangkabau Menjadi Tanah Hak Milik," Lentera
Huk., vol. 5, no. 3, pp. 392-407, 2018, doi: 10.19184/ejlh.v5i3.8291.

Sjahmunir, Eksistensi Tanah Ulayat dalam Perundang-undangan di Indonesia. Padanh: PPIM, 2000.

M. Munir, "Sistem Kekerabatan dalam kebudayaan Minangkabau Perspektif Aliran Filsafat Strukturalisme Jean Claude LeviStrauss," J. filsafat, vol. 25, no. 1, p. $1,2015$.

Nasroen. M, Dasar Falsafah Adat Minangkabau. Jakarta: Bulan Bintang, 1971.

R. Syarfina, "Pengaruh Hukum Adat Dalam Proses Peralihan Hak Tanah Ulayat Pada Pembangunan Perluasan Bandara Di Jayapura," Otentik's J. Huk. Kenotariatan, vol. 1, no. 1, pp. 47-53, 2019.

HS Salim dan Erlies Septianan Nurbaini, Penerapan Teori Hukum Pada Penelitian Tesis dan Disertasi. Jakarta: Raja Grafindo Persada, 2016.

E. Ikhsan, Konflik Tanah Ulayat dan Pluralisme Hukum. Jakarta: Yayasan Pustaka Obor Indonesia, 2016.

A. Hartanto, Problematika Hukum Jual Beli Tanah Belum Bersertifikat. Yogyakarta: Laksbang Mediatama, 2012.

K. Mohammad Jeffry Maulidi, M. Arba, "Analisis Hukum Tentang Peralihan Hak Milik Atas Tanah Dengan Bukti Akta Di Bawah Tangan Sebagai Dasar Pendaftaran Tanah Untuk Pertama Kali (Studi Di Kabupaten Lombok Tengah)," J. 
Ratih Agustin Wulandari, Muhammad Sukron, Raimon Efendi: Analisa Hukum...

Kaji. Huk. dan keadilan, vol. Desemeber, pp. 415-427, 2017.

B. Muhammad, Pokok-Pokok hukum adat. Jakarta: Pradnya Paramitha, 1991.

Titin Fatimah dan Hengki Andora, "Pola Penyelesaian Sengketa Tanah Ulayat di Sumatera Barat (Sengketa antara Masyarakat dengan
Investor)," J. Ilmu Huk., vol. 4 no 1, pp. 36-75.

H. I. Abdul Mutolib , Yonariza , Mahdi, "Konflik Agraria Dan Pelepasan Tanah Ulayat ( Studi Kasus Pada Masyarakat Suku Melayu di $\mathrm{Ke}$ Satuan Pemangkuhan Hutan Dharmasraya , Sumatera Barat )," $J$. Penelit. Sos. Ekon. Kehutan., vol. 12 Nomor 3, pp. 213-225, 2015. 